\title{
Vessel for Drowning Persons?
}

\section{The Standard-Setting Potential of International Human Rights Litigation in Addressing Climate Displacement}

\author{
Margaretha Wewerinke* and Melina Antoniadis**
}

Human rights litigation has gained increasing importance as a mechanism for holding governments or corporations to account for climate change action or inaction. A distinct category of this rights-based climate litigation concerns the rights of people faced with deportation to locations where their rights may be compromised as a result of climate change. ${ }^{1}$ In addition, a small number of cases has focused on the rights of those who face internal displacement as a result of climate change impacts. ${ }^{2}$ To date, none of these cases has resulted in a court victory for the plaintiffs, thus highlighting rather than closing the gaps in legal protection afforded to climate displaced persons. In 2019, however, the UN Human Rights Committee issued a decision in which it recognised that States have an obligation to refrain from returning asylum seekers to another State where their life or physical integrity would be at serious risk because of

\footnotetext{
* $\quad$ Assistant Professor of Public International Law, Grotius Centre for International Legal Studies (Leiden University), Adjunct Senior Lecturer in Environmental Law, Pacific Centre for Environment and Sustainable Development (University of the South Pacific).

** Research Associate, Grotius Centre for International Legal Studies (Leiden University), Member of the Law Society of Ontario.

*** The authors wish to thank Marlies Hesselman and two anonymous reviewers for helpful feedback.

1 See e.g., AF (Kiribati) [2013] NZIPT 800413 (N.z.); Teitiota v. The Chief Executive of the Ministry of Business, Innovation and Employment [2013] NZHC3125 (N.z.); Teitiota v. The Chief Executive of the Ministry of Business, Innovation and Employment [2014] NZCA 173 (N.Z.); Teitiota v. The Chief Executive of the Ministry of Business Innovation and Employment [2015] NZSC 107 (N.Z.); AF (Tuvalu) [2015] NZIPT 800859 (N.Z.); AD (Tuvalu) [2014] NZIPT 501370 (N.z.); AC (Tuvalu) [2014] NZIPT 800517-520 (N.z.).

2 The case is known as 'Billy et al. v. Australia' or 'the Torres Strait Islanders case'. See also ClientEarth, 'Climate threatened Torres Strait Islanders bring human rights claim against Australia' (ClientEarth, 12 May 2019) <https://www.clientearth.org/latest/press-office/ press/climate-threatened-torres-strait-islanders-bring-human-rights-claim-againstaustralia/> last accessed (as any subsequent URL) on 27 April 2021.
}

(C) MARGARETHA WEWERINKE AND MELINA ANTONIADIS, 2022｜ DOI:10.1163/26662531_00301_010 
the adverse effects of climate change. This case, Teitiota v. New Zealand, ${ }^{3}$ was brought by a citizen of Kiribati who had been denied asylum in New Zealand despite his claims that climate change made Kiribati uninhabitable. The case was dismissed on the merits, and the reasoning of the Committee leaves much to be desired. ${ }^{4}$ Nonetheless, the Committee's assertion that States' discretion to return people to places where climate-related risks cross human rights thresholds signals a potential role for international human rights litigation in enhancing protection of climate displaced persons.

Following 'Teitiota', two more climate cases have been filed before human rights treaty bodies, both of which address climate displacement in one way or another. The first of those is currently pending before the Human Rights Committee, filed by a group of eight Torres Strait Islanders who are experiencing regular flooding of their land and homes as a result of sea level rise and higher king tides. ${ }^{5}$ The other is a case filed to the UN Committee on the Rights of the Child on behalf of sixteen minors, which touches on the link between climate displacement and mental health problems. ${ }^{6}$ In addition, a complaint filed in 2020 by the Alaska Institute for Justice on behalf of five US Indian tribes is currently being considered by ten UN Special Rapporteurs. ${ }^{7}$ The latter complaint is one of the first to address internal displacement from climate change head-on, with the petitioners calling on the Special Rapporteurs to intervene, investigate and recommend concrete measures to address climate displacement.

Drawing on these recent developments, this contribution considers the actual and potential role of international human rights mechanisms in closing

3 UNHRC, 'Views adopted by the Committee under article 5 (4) of the Optional Protocol, concerning communication No. 2728/2016' (24 October 2019) CCPR/C/127/D/2728/2016 ['Teitiota v. New Zealand'].

4 See section 2.3.

5 See 'Billy et al. v. Australia' (n 2).

6 The case is known as 'Sacchi et al v. Argentina et al.. The communication was filed to the Committee on the Rights of the Child (23 September 2019) <https://earthjustice.org/sites/ default/files/files/2019.09.23-crc-communication-sacchi-et-al-v.-argentina-et-al-redacted .pdf> ['Sacchi et al v. Argentina et al.']. The admissibility decisions appeared at the time of going to press and can be accessed here: <https://tbinternet.ohchr.org/_layouts/15/treatybodyexternal/SessionDetails1.aspx?SessionID=1351\&Lang=en $>$. For a detailed case note on the decisions, see Margaretha Wewerinke-Singh, 'Communication 104/2019 Chiara Sacchi et al v. Argentina et al.' (Leiden Children's Rights Observatory, 28 October 2021) <https://www. childrensrightsobservatory.nl/case-notes/casenote2021-10>.

7 The complaint is titled 'Rights of Indigenous People in Addressing Climate-Forced Displacement' (15 January 2020) <http://climatecasechart.com/climate-change-litigation/wp -content/uploads/sites/16/non-us-case-documents/2020/20200116_NA_complaint.pdf>. 
the gaps in legal protection afforded to climate displaced persons. In their assessment of claims, these mechanisms apply open-textured provisions of human rights treaties to specific facts, often resulting in the articulation or development of specific standards which constitute authoritative guidance to States Parties on the implementation of treaties in respect of specific rights or issues. In the context of climate displacement, such standards are lacking, and as a result, States are able to ignore or deny the existence of obligations towards climate displaced persons. This type of litigation therefore provides the opportunity for these human rights mechanisms to clarify the scope of protection available under international human rights law, which in turn can affect State practice as well as decisions of international, regional and domestic courts and quasi-judicial bodies.

Climate displacement has been defined as 'the involuntary movement of people, caused by the effects of climate change.' 8 It is understood that displacement in the context of climate change is often multi-causal, and much movement related to environmental factors is not entirely forced or voluntary, but rather falls somewhere on a continuum between the two. ${ }^{9}$ For our purposes, the term 'climate displaced persons' is used to include those who are forced or obliged to leave their homes or places of habitual residence, in particular as a result of or in order to avoid the effects of disasters triggered by natural hazards, and those who plan to relocate due to a climate event, both within a country and across international borders.

This contribution first identifies the features of UN human rights treaty bodies that enable it to contribute to the legal standard-setting on the protection of climate displaced persons. It then assesses the Human Rights Committee's views in 'Teitiota v. New Zealand' and its (limited) contribution to such standard-setting. The 'Teitiota' case is the first and so far the only case before a UN human rights treaty body that addresses cross-border climate displacement, and the first climate case before a UN human rights treaty body that has resulted in a decision. It thus provides insight into the potential role of treaty bodies in addressing climate change-related violations, and specifically, with respect to cross-border climate displacement. This section also discusses the standard-setting prospects of pending climate cases, namely 'Billy et al. v. Australia' and 'Sacchi et al v. Argentina et al.', which address climate

8 Walter Kalin, 'Conceptualising Climate-Induced Displacement' in Jane McAdam (ed), Climate Change and Displacement: Multidisciplinary Perspectives (Hart 2010) 82.

9 HR Council, "The Slow onset effects of climate change and human rights protection for crossborder migrants' (22 March 2018) UN Doc A/HRC/37/CRP.4. 
displacement directly or indirectly, and provide a useful understanding on how climate cases are being framed before human rights treaty bodies.

The second part of the article discusses the actual and potential role of Special Procedure mechanisms of the UN Human Rights Council in legal standard-setting on climate displacement, with particular attention to the complaint addressed to ten UN Special Rapporteurs by the Alaska Institute for Justice on behalf of five US Indian tribes. We conclude with reflections on how litigants and international human rights mechanisms could contribute to enhanced legal protection of climate displaced persons in the future.

\section{Potential of UN Human Rights Treaty Bodies to Contribute to Standard-Setting on Climate Displacement through Complaint Mechanisms}

The UN human rights treaty bodies, established to monitor the implementation of the human rights treaties, have significant potential to contribute to enhanced legal protections for climate displaced persons. These treaty bodies could - and to an extent already do - monitor the implementation of States' obligations to respect, protect, and fulfil human rights in the context of climate displacement, while also further elaborating these obligations thereby closing existing legal protection gaps. The complaint mechanisms of the UN human rights treaty bodies, which so far have remained under-utilised, are key in ensuring that this potential is fully realised..$^{10}$

Given that human rights treaties tend to be drafted in an open-textured manner, human rights treaty bodies are crucial in interpreting their provisions. ${ }^{11}$ Human rights treaty bodies have the authority to define and interpret the obligations contained in treaties and elaborate the scope and protection of human rights consistent with the treaty provisions. Indeed, States have conferred a monitoring role on these treaty bodies, which consists of gathering the information, developing a body of jurisprudence and engaging in constructive dialogue in order to move States parties to achieve the effective implementation of the treaty's rights. ${ }^{12}$ Consequently, the jurisprudence produced by

10 See also Matthew Scott, 'A Role for Strategic Litigation' (2015) 49 Forced Migration Review: Disasters and Displacement in a Changing Climate, $47-48$.

11 Kasey L. McCall-Smith, 'Interpreting International Human Rights Standards' in Stéphanie Lagoutte, Thomas Gammeltoft-Hansen and John Cerone (eds), Tracing the Roles of Soft Law in Human Rights (OUP 2016) 27.

12 Dinah Shelton, 'The Legal Status of Normative Pronouncements of Human Rights Treaty Bodies' in Holger Hestermeyer et al., Coexistence, Cooperation and Solidarity (Rüdiger Wolfrum 2011) 559 . 
these bodies can guide interpretation and State practice in the international and domestic spheres.

\subsection{UN Human Rights Treaty Bodies and Climate Change}

UN human rights treaty bodies are committees of independent experts established under the international human rights treaties responsible for monitoring States' compliance with the legal obligations contained in those treaties. There are currently ten such treaty bodies, each comprised of 10 to 23 independent experts appointed by the treaties' State Parties..$^{13}$ These treaty bodies have three main functions. ${ }^{14}$ First, they are responsible for publishing General Comments which are authoritative interpretations of treaties, either on specific rights, specific provisions of the treaty or a related thematic practice. This process involves general discussion days and consultations and the opportunity to make written submissions. Second, UN treaty bodies assess individual complaints about alleged violations of the treaty by a State, and issue non-binding 'Views' on those cases. Third, treaty bodies assess reports submitted by States to the treaty body on the steps they have taken towards the implementation of the treaty, along with information provided by other sources, including civil society. After holding a 'Dialogue' with the State to discuss implementation, the treaty body issues its 'Concluding Observations', which provides its assessment of the State's performance. ${ }^{15}$

Since 2008, UN human rights treaty bodies have addressed climate change and human rights in a number of statements, views, concluding observations, ${ }^{16}$

13 UN онснR, 'Monitoring the core international human rights treaties' <https://www .ohchr.org/EN/HRBodies/Pages/Overview.aspx>.

14 See Nigel S Rodley, 'Ch. 26 The Role and Impact of Treaty Bodies' in Dinah Shelton (ed), The Oxford Handbook of International Human Rights Law (oup 2013) 626: 'There are five typical functions that the treaties may contemplate for the committees: first, review of reports that states undertake to submit after becoming party to the treaty; second, at least implicitly, general comments on the nature and scope of the treaties' provisions; third, interstate complaints; fourth, individual complaints; and fifth, inquiries into general practices that violate the respective treaty'.

15 Center for International Environmental Law (CIEL) and the Global Initiative for Economic, Social and Cultural Rights, 'States' Human Rights Obligations in the Context of Climate Change - Synthesis Note on the Concluding Observations and Recommendations on Climate Change Adopted by UN Human Rights Treaty Bodies' (2018) <https:// www.ciel.org/wp-content/uploads/2018/o1/HRTBs-synthesis-report.pdf> 4 .

16 See for example, HRC, 'Concluding Observations on the initial report of Cabo Verde' (7 November 2019) CCPR/C/CPV/CO/1/Add.1. 
General Comments and General Recommendations. ${ }^{17}$ This body of work provides guidelines for the interpretation and application of State party obligations deriving from the respective Covenants and Conventions in relation to climate action, and constitutes part of the evolving international human rights law framework that is increasingly addressing climate change. Examples include General Comments and General Recommendations affirming that States' obligations under international environmental law should inform the right to life and vice versa, ${ }^{18}$ assessing the gender-related dimensions of disaster risk reduction in the context of climate change, ${ }^{19}$ confirming the impact and relevance of climate change on children's health, ${ }^{20}$ and recommending that, in adopting strategies to ensure that there is sufficient and safe water for present and future generations, States should assess the impacts of actions that may impinge upon water availability and natural-ecosystems watersheds, such as climate changes, desertification and increased soil salinity, deforestation and loss of biodiversity. ${ }^{21}$

For the purpose of the present article, particularly relevant are treaty bodies' statements focusing specifically on climate migration and displacement. The CEDAW, for instance, noted in its General Recommendation No. 37 on Gender-related dimensions of disaster risk reduction that disasters and climate change are among the push factors for women's migration, and in several regions, are contributing to an increase in the feminization of migration. ${ }^{22}$ Its Concluding Observations on the periodic reports of Tuvalu reiterated recommendations that Tuvalu ' $[\mathrm{d}]$ evelop disaster management and mitigation plans in response to potential displacement and/or statelessness arising from environmental and climate change and ensure that women, including those living on the outer islands, are included and may actively participate in planning and decision-making processes concerning their adoption. ${ }^{23}$ The Committee

17 UN онснR, 'Human rights mechanisms addressing climate change' <https://www.ohchr .org/EN/Issues/HRAndClimateChange/Pages/HumanRightsMechanisms.aspx $>$.

18 CCPR, 'General Comment No. 36 (2018) on article 6 of the International Covenant on Civil and Political Rights, on the right to life' (3o October 2018) CCPR/C/GC/36, para. 62.

19 CEDAW, 'General Recommendation No. 37 on Gender-related dimensions of disaster risk reduction in the context of climate change' (7 February 2018) CEDAW/C/GC/37.

20 CRC, 'General Comment No. 15 (2013) on the right of the child to the enjoyment of the highest attainable standard of health (art. 24)' (17 April 2013) CRC/C/GC/15, paras. 5, 50.

21 CESCR, 'General Comment No. 15: The Right to Water (Arts. 11 and 12 of the Covenant)' (20 January 2003) E/C.12/2002/11, para. 28.

22 See General Recommendation No. 37 (n 19).

23 CEDAW, 'Concluding observations on the combined third and fourth periodic reports of Tuvalu' (11 March 2015) CEDAW/C/TUV/CO/3-4. 
on Migrant Workers, in its turn, noted that natural hazards and climate change are structural causes that lead to forced migration. ${ }^{24}$ More recently, in Concluding Observations on Tuvalu, the Federated States of Micronesia and the Cook Islands, the Committee on the Rights of the Child noted that international migration in the context of climate change and natural disasters may increasingly affect children, and recommended that the State party consider developing legislation, policies and programmes governing the international migration of children that take into account the rights and needs of children. ${ }^{25}$ Finally, five treaty bodies issued a joint statement on human rights and climate change, acknowledging that migration is 'a normal human adaptation strategy in the face of the effects of climate change and natural disasters, as well as the only option for entire communities and has to be addressed by the United Nations and the States as a new cause of emerging migration and internal displacement'. ${ }^{26}$ The statement also recommended that states should offer complementary protection mechanisms for migrant workers 'displaced across international borders in the context of climate change and disasters'. ${ }^{27}$

\subsection{Potential of UN Human Rights Treaty Bodies to Contribute to Standard-Setting on Climate Displacement through Complaints Procedures}

With their contribution to the general climate change conversation in mind, UN human rights treaty bodies appear to be particularly well-positioned to consider individual complaints regarding climate displacement for three reasons. First, UN human rights complaint mechanisms are able to consider cases based on international legal norms that embody globally shared values and reflect a plurality of legal traditions. ${ }^{28}$ The Universal Declaration of Human Rights ('UDHR'), for instance, evolved out of 'a commingling of diverse traditions and attitudes', and may therefore be seen as proof of global agreement on 'certain fundamentals as commanding acceptance across all barriers of creed

24 CMW, 'Concluding observations on the second periodic report of Guatemala' (2 May 2019) $\mathrm{CMW} / \mathrm{C} / \mathrm{GTM} / \mathrm{CO}_{2}$.

$25 \mathrm{CRC}$, 'Concluding observations on the combined second to fifth periodic reports of Tuvalu' (31 March 2020) CRC/C/TUV/CO/2-5; CRC, 'Concluding observations on the combined second to fifth periodic reports of the Federated States of Micronesia' (3 April 2020) $\mathrm{CRC} / \mathrm{C} / \mathrm{FSM} / \mathrm{CO} / 2$; $\mathrm{CRC}$, 'Concluding observations on the combined second to fifth periodic reports of the Cook Islands' (2 April 202O) CRC/C/COK/CO/2-5.

26 UN онснR, 'Five UN human rights treaty bodies issue a joint statement on human rights and climate change' (16 September 2019) <https://www.ohchr.org/EN/NewsEvents/ Pages/DisplayNews.aspx?NewsID=24998>.

27 Ibid.

28 Christopher G. Weeramantry, Universalising International Law (Brill Publishing 2004). 
and color and historical tradition. ${ }^{29}$ The mandates of UN human rights treaty bodies are derived from core human rights treaties that protect the rights contained in the UDHR as well as the rights of particular groups such as women, children and persons with disabilities. International human rights law, as embodied in these various sources, 'forms an integral, universal system, allowing and encouraging interpreters to reach into the melting pot where national and international legal orders and jurisprudence mix and enrich human rights, with the purpose of improving the consistency and reach of the norms they have to apply' ${ }^{30}$ The widespread adoption and similarities in formulations of human rights across diverse legal instruments, including human rights treaties, makes human rights particularly suited as the basis for the development of an international jurisprudence on climate displacement. ${ }^{31}$ With respect to climate displacement, the need to cooperate internationally to tackle its root causes further increases the importance of human rights norms that have a universal or quasi-universal applicability. As one scholar sums up, the work of human rights treaty bodies 'provides sufficient flexibility coupled with legal certainty by which to define a credible standard for the reconciliation of tensions between the diversity of cultural practices on the one hand and the universal respect for human rights on the other'. ${ }^{32}$

Second, despite not being binding per se, the decisions or recommendations issued by UN human rights mechanisms do have significant legal impact. This arises in part because most core human rights treaties are nearuniversally ratified. The International Covenant on Civil and Political Rights ('ICCPR'), for example, has 173 State parties, including all high-income States listed in Annex I to the UN Framework Convention on Climate Change. The International Covenant on Economic, Social and Cultural Rights ('ICESCR') has been ratified by ${ }_{171}$ States, also including the vast majority of high-income States, and the CRC is ratified by all States except the United States. ${ }^{33}$ The number of ratification of these treaties has risen rapidly in recent years, with all UN

29 Ibid., 2.

30 Cecilia Medina, 'Ch. 27 The Role of International Tribunals: Law-Making or Creative Interpretation?' in Dinah Shelton (ed), The Oxford Handbook of International Human Rights Law (OUP 2013) 652 .

$31 \quad J a c q u e l i n e$ Peel and Hari Osofsky, 'A Rights Turn in Climate Change Litigation?' (2017) 7 Transnational Environmental Law, 40.

32 Michael K. Addo, 'Practice of United Nations Human Rights Treaty Bodies in the Reconciliation of Cultural Diversity with Universal Respect for Human Rights' (2010) 32 Human Rights Quarterly, 615.

33 For ratification status, see United Nations Treaty Collection (UNTC), 'Multilateral Treaties Deposited with the Secretary-General' <https://treaties.un.org/Pages/ParticipationStatus .aspx?clang=_en $>$. 
Member States having ratified at least one core human rights treaty and 80 per cent having ratified four or more. ${ }^{34}$ While, as noted, decisions of human rights treaty bodies are not legally binding, the reasoning of such decisions reflects the treaty bodies' authoritative interpretation of these treaties to which the States parties have agreed to be legally bound. As noted above, human rights treaties are drafted with broad language, leaving the specifics for later elaboration through processes such as delegation to treaty bodies and acquiescence in the procedures they adopt. Accordingly, these treaties have developed through subsidiary rules and the unwritten practices of treaty bodies they establish. States therefore leave it to treaty bodies to interpret the general articulation of rights they have agreed on. ${ }^{35}$

The authority of UN human rights treaty bodies is most apparent in situations where they pronounce on issues of violation of the treaties and where they otherwise interpret treaty provisions. ${ }^{36}$ 'Views' on the merits of complaints, in particular, have received the most attention as a source of normative development. The role of treaty bodies consists of the application of treaty provisions to specific facts and conclusions about whether those facts reveal the violation of a human right under the treaty. These views are therefore instructive to all States parties, and not only to the State concerned in the complaint. ${ }^{37}$ With respect to the UN Human Rights Committee, commentators have expressed that although the views of the Committee are not legally binding on the State party concerned, such views 'gain their authority from their inner qualities of impartiality, objectivity and soberness. If such requirements are met, the views of the [Committee] can have a far-reaching impact. ${ }^{38}$ The Committee, it has been stated, has, within the limits of its powers, followed an increasingly judicial method of operation.' ${ }^{39}$ With respect to concluding observations, a former Committee member, Vojin Dimitrijevic, revealed: 'a statement of an authoritative body performing an important supervisory function cannot remain without consequences'. ${ }^{40}$ Within the context of a finding by a treaty body of a violation of the treaty in question, another former Committee member,

34 See UN онснг, 'Ratification of 18 International Human Rights Treaties' <https://indica tors.ohchr.org/>.

35 See Dinah Shelton, The Legal Status of Normative Pronouncements (n 12) 56o.

36 Michael O'Flaherty, 'The Concluding Observations of United Nations Human Rights Treaty Bodies' (2006) 6 Human Rights Law Review, 36.

37 See Dinah Shelton, The Legal Status of Normative Pronouncements (n 12) 567 .

38 Christian Tomuschat, 'Evolving Procedural Rules: The United Nations Human Rights Committee's First Two Years of Dealing with Individual Communications' (1980) 1 H RLJ, 255.

39 Laurence R. Helfer and Anne-Marie Slaughter, 'Toward a Theory of Effective Supranational Adjudication' (1997) 107 Yale Law Journal, 280-281.

40 Vojin Dimitrijevic, 'State Reports' in Alfredsson et al. (eds), International Human Rights Monitoring Mechanisms: Essays in Honour of Jakob Th. Moiler (Martinus Nijhof 2001) 198. 
Martin Scheinin, has likewise highlighted the legal significance of the treaty body's practice:

The treaty obligations themselves, are, naturally, legally binding, and the international expert body established by the treaty is the most authoritative interpreter of the treaty in question. Therefore, a finding of a violation by UN human rights treaty body may be understood as an indication of the State party being under a legal obligation to remedy the situation. ${ }^{41}$

Apart from informing State practice under these treaties, the reasoning of UN human rights bodies with respect to climate displacement can guide national and regional courts in their decision-making under related human rights treaties or domestic constitutions. Indeed, while the practice of these bodies may influence the interpretation and development of treaties in the international legal order, the main rationale of human rights treaty monitoring mechanisms is that they affect the protection of human rights at the domestic level. ${ }^{42}$ As such, if treaty bodies, in their views and concluding observations, were to clarify the scope of legal protection for climate displaced peoples, and thereby interpret the law against a specific factual scenario of climate displacement, this could potentially provide national courts and regional courts with a standard of protection which would assist them in closing any protection gaps.

Third, the membership of UN human rights treaty bodies is more geographically diverse than that of most other judicial or quasi-judicial bodies that have been confronted with climate change cases. In addition to seeking to achieve equitable geographical distribution, the treaty body election guidelines also seek to achieve representation of different types of civilisations and legal systems among the States parties, which helps ensure that no one region or culture dominates. ${ }^{43}$ Most important in connection with climate displacement is that each of the treaty bodies includes members from regions and countries that are particularly vulnerable to the adverse effects of climate change. ${ }^{44}$ It is understood that climate change is disproportionately felt by

41 Martin Scheinin, 'International Mechanisms and Procedures for Implementation' in Hanski and Suksi (eds), An Introduction to the International Protection of Human Rights: A Textbook (Turku/Abo: Institute for Human Rights, Abo Akademi 1997) 369 .

42 Rosanne Van Alebeek and André Nollkaemper, 'The Legal Status of Decisions by Human Rights Treaty Bodies in National Law', in Hellen Keller and Geir Ulfstein (eds), UN Human Rights Treaty Bodies (CUP 2012) 356.

43 See Kasey L. McCall-Smith (n 11) 29.

44 The Office of the UN High Commissioner for Human Rights reports that, as at 1 January 2019, the distribution of treaty body members amongst regional groups was at follows: $27 \%$ African, $17 \%$ Asia-Pacific, $17 \%$ Eastern European, 19\% Latin American and Caribbean and 
persons in vulnerable situations, particularly 'those living in geographically vulnerable developing countries. ${ }^{45}$ Climate displacement is already a reality in many climate vulnerable States, and is projected to increase further as climate impacts worsen. ${ }^{46}$ Diversity within the UN human rights treaty bodies would help to better understand the needs of different individuals or groups of individuals when assessing cases of climate change-related displacement and the relevant legal obligations. It would thus enable these bodies 'to simultaneously consider the relative contributions of States from different regions to the alleged human rights violations of climate change.47

The use of complaint procedures of UN human rights treaty bodies is important to standard-setting because the application of the open-textured provisions of human rights treaties to specific facts often results in the articulation or development of more specific standards. Legally, these specific standards constitute authoritative guidance to States Parties on the implementation of treaties in respect of specific rights or issues. In the case of climate displacement, specific standards are lacking, which as a result, enables States to ignore or deny the existence of obligations towards climate displaced persons. Adjudication is a way for human rights treaty bodies to demonstrate that these treaties do actually provide protection and thus there is not so much of a protection gap as there may at first seem to be. Conversely, denying protection in these cases highlights the existence of a protection gap. In other words, this type of litigation clarifies the scope of protection available under international human rights law, which in turn can affect State practice as well as decisions of international, regional and domestic courts and quasi-judicial bodies. ${ }^{48}$

20\% Western European and Others. See UN онснR, 'Elections of Treaty Body Members' <https://www.ohchr.org/EN/HRBodies/Pages/ElectionsofTreatyBodiesMembers.aspx>. HC Council 'Analytical study on the relationship between climate change and the human right of everyone to the enjoyment of the highest attainable standard of physical and mental health' (6 May 2016) UN Doc A/HRC/32/23, para. 21.

46 The Nansen Initiative, 'Agenda for the Protection of Cross-Border Displaced Persons in the Context of Disasters and Climate Change - Volume I' (2015) <https://disasterdisplacement.org/wp-content/uploads/2014/o8/EN_Protection_Agenda_Volume_I_low_res.pdf > paras. 6, 43. See also UN Doc A/HRC/32/23 (n 45) para. 23 .

47 Margaretha Wewerinke-Singh, 'Litigating Human Rights Violations Related to the Adverse Effects of Climate Change in the Pacific Islands' in Jolene Lin and Douglas A Kysar (eds), Climate Change Litigation in the Asia Pacific (CUP 2O2O) 98.

48 See Matthew Scott (n 10). See also Center for International Environmental Law (CIEL) and the Global Initiative for Economic, Social and Cultural Rights, 'States' Human Rights Obligations in the Context of Climate Change - 2020 Update' (2020) <https://www.ciel .org/wp-content/uploads/2020/o3/States-Human-Rights-Obligations-in-the-Context-of -Climate-Change_2O2O-Update.pdf $>$ 1. 


\subsection{The Human Rights Committee's Views and Its Contribution to Standard-Setting in 'Teitiota v. New Zealand'}

In 2015, the UN Human Rights Committee examined the first case concerning climate displacement, filed before a UN human rights treaty body. The author of the complaint was Ioane Teitiota, a citizen of the low-lying island State of Kiribati. Teitiota claimed that sea level rise and other adverse effects of climate change, such as insufficient fresh water, overcrowding, inundation, erosion and land disputes, had forced him to migrate from Kiribati to New Zealand. ${ }^{49}$ Upon the expiry of his visa in New Zealand, Teitiota made a claim for asylum which was denied by the Immigration and Protection Tribunal. ${ }^{50}$ The New Zealand High Court, Court of Appeal, ${ }^{51}$ and Supreme Court ${ }^{52}$ subsequently all upheld the Tribunal's decision. As a consequence, Teitiota along with his wife and children, were deported from New Zealand to Kiribati.

In what had become a long-standing test case for speculation on the application of international law to climate displacement, Teitiota filed a complaint to the Human Rights Committee under the First Optional Protocol to the ICCPR, seeking to prevent his deportation. ${ }^{53}$ In this complaint, he alleged that New Zealand's decision to deport him put him in a situation where he would face a risk of threat to his life. Specifically, Teitiota argued that the decision of the authorities to deport him constituted a violation of New Zealand's obligations to protect the right to life under Article 6 of the ICCPR. On the facts, he claimed that sea level rise in Kiribati has resulted in: (a) 'the scarcity of habitable space, which has in turn caused violent land disputes that endanger [his] life', and (b) 'environmental degradation, including saltwater contamination of the freshwater supply'.54

On admissibility, the Committee explained that the question was whether Teitiota has substantiated the claim that he faced upon deportation a real risk of irreparable harm to life. It noted that Teitiota's claims in relation to the conditions on Tarawa, the capital of Kiribati, at the time of his removal did not concern a hypothetical future harm, but a real predicament or risk caused by lack of potable water and employment possibilities, and a threat of serious

\footnotetext{
49 Jane McAdam, 'Protecting People Displaced by the Impacts of Climate Change: The UN Human Rights Committee and the Principle of Non-refoulement' (2020) 114/4 AJIL, 709.

50 See $A F$ (Kiribati) [2013] NZIPT 800413 (n 1).

$5^{1}$ See 'Teitiota v. The Chief Executive of the Ministry of Business Innovation and Employment' [2014] NZCA 173 (n 1).

52 See 'Teitiota v. The Chief Executive of the Ministry of Business, Innovation and Employment' [2015] NZSC 107 (n 1).

53 See 'Teitiota v. New Zealand' (n 3 ) para. 8.5.

54 Ibid, para. 3.
} 
violence caused by land disputes. ${ }^{55}$ Based on the information provided, the Committee considered that this was sufficiently demonstrated by Teitiota.

On the merits, the Committee's decision rested on an assessment whether, in evaluating Teitiota's claim that if returned to Kiribati he would face a risk of threat to his life, there was 'clear arbitrariness, error or injustice' by the New Zealand authorities. ${ }^{56}$ Referring to General Comment No. 36, the Committee expressed that the risk must be personal and cannot derive merely from the general conditions in the receiving State, except in the most extreme cases. ${ }^{57}$ Before addressing each of the claims, the Committee reiterated that environmental degradation can adversely affect an individual's well-being and lead to a violation of the right to life. ${ }^{58}$

With respect to violent land disputes, the Committee found that there was an absence of a situation of general conflict in Kiribati and that Teitiota had never been involved in such a land dispute. The Committee noted that there was an absence of information with respect to a lack of State protection against non-state actors who engage in violence in such disputes. As a result, it was held that Teitiota had not demonstrated that there was a clear error in New Zealand's assessment of there not being a real, personal and reasonably foreseeable threat to Teitiota's right to life. ${ }^{59}$

With respect to the lack of potable water, while the Committee noted that more than half of the residents of South Tarawa obtained fresh water from rationed supplies provided by the public utilities board and recognized that hardship may be caused by water rationing, it nonetheless concluded that there was insufficient indication that the supply of fresh water is inaccessible, insufficient or unsafe to produce a reasonably foreseeable threat of a health risk so as to impair Teitiota's 'right to enjoy a life with dignity, or cause his unnatural or premature death' 60

With respect to the lack of land to grow food, the Committee took note of Teitiota's assertion that while it was difficult to grow crops, it was not impossible. It stated that there was a lack of evidence of information provided on alternative sources of employment and on the availability of financial assistance to meet the needs of Kiribati, and noted that the most nutritious crops remained available in Kiribati. The Committee thus found that there was not a

\begin{tabular}{ll}
\hline 55 & Ibid. \\
56 & Ibid, para. 9.6. \\
57 & Ibid, para. 9.3. \\
58 & Ibid, para. 9.5 \\
59 & Ibid, para. 9.7. \\
60 & Ibid, para. 9.8.
\end{tabular}


real and reasonably foreseeable risk that Teitiota would be exposed to deprivation of food that could threaten his right to life. ${ }^{61}$

Finally, with respect to increased flooding, the Committee accepted that the risk of an entire country becoming submerged under water is such an extreme risk the conditions of life in such a country may become incompatible with the right to life with dignity before the risk is realised. The Committee accepted Teitiota's case that sea level rise is likely to render Kiribati uninhabitable, ${ }^{62}$ and appeared to accept 10 to 15 years as a timeframe, but nonetheless found that the timeframe could allow for intervening acts by the government of Kiribati. ${ }^{63}$ The Committee found that based on the information, it was not in a position to conclude that the assessment made by New Zealand with respect to the measures taken by Kiribati to protect Teitiota's right to life was arbitrary or erroneous, or amounted to a denial of justice. ${ }^{64}$

As a general point, the decision of the Human Rights Committee is considered 'a landmark determination', 65 as it confirmed the availability of complementary protection for the right to life of people displaced across international borders for reasons associated with climate change. ${ }^{66}$ This is important in the sense that 'as climate impacts worsen, future similar claims might well succeed' ${ }^{67}$ All in all, the Committee's decision is significant in that it explicitly recognised that the impacts of climate change 'may themselves be a bar to deportation'.68 Further, the 'Teitiota' decision has arguably opened the door to claims by individuals seeking asylum protection from the effects of climate change and has forged a path towards establishing an alternative asylum framework through the ICCPR. ${ }^{69}$ Indeed, the Committee stated that even where climate-induced asylum seekers are not entitled to refugee status, receiving States have human rights obligations not to deport or to refoul them where returning them to their State of origin would lead to the violation of

\footnotetext{
$61 \quad$ Ibid, para. 9.9.

$62 \quad$ Ibid, para. 9.11.

$63 \quad$ Ibid, para. 9.12.

64 Ibid, paras. 9.12, 9.13.

65 See Jane McAdam, Protecting People (n 49) 709.

66 Miriam Cullen, 'The UN Human Rights Committee's Recent Decision on Climate Displacement' (Asylum Insight, February 2020) <https://www.asyluminsight.com/c-miriam -cullen?rq=cullen\&num;:XlcOITIzaOU\#.YIRcv2dKjIU>.

67 Ibid.

68 See Jane McAdam, Protecting People (n 49) 710.

69 UN онснг, 'Historic UN Human Rights case opens door to climate change asylum claims' (21 January 2020) <https://www.ohchr.org/en/NewsEvents/Pages/DisplayNews .aspx?NewsID=25482\&LangID=E $>$.
} 
their right to life. ${ }^{70}$ The decision of the Committee is therefore significant in that it broadened the scope of asylum and non-refoulement protection under the ICCPR to the category of climate-induced asylum seekers. ${ }^{71}$

That being said, the Human Rights Committee's contribution to standardsetting, in its decision, was significant but not without problems. It appears from the decision and the Committee's deference to the New Zealand courts that it requires an impossibly high level of proof to substantiate that the situation in a climate migrants' country of origin has already become life-threatening. According to the standard set out by the Committee, for Teitiota's removal to be precluded with respect to violence during land disputes in Kiribati, Teitiota would have to prove before the domestic courts that he faced 'a real, personal and reasonably foreseeable risk of a threat to his right to life as a result of violent acts resulting from overcrowding or private land disputes in Kiribati' ${ }^{72}$ By that same standard, with respect to the lack of potable water in Kiribati, Teitiota would have had to prove that 'the supply of fresh water [was] inaccessible, insufficient or unsafe so as to produce a reasonably foreseeable threat of a health risk that would impair his right to enjoy a life with dignity or cause his unnatural or premature death. ${ }^{73}$ The suggestion appears to be that the drinking water must be undrinkable and not merely risky or somewhat dangerous. ${ }^{74}$ Further, with respect to difficulties in growing crops, he would have had to show that there was 'a real and reasonably foreseeable risk' that he would be 'exposed to a situation of indigence, deprivation of food, and extreme precarity that could threaten his right to life, including his right to a life with dignity. ${ }^{\prime 5}$ Again, the suggestion here seems to be that there must be a complete failure of crops rather than merely a decline. ${ }^{76}$ The decision can thus be interpreted as meaning that there has to be a 'complete breakdown in the means of life to justify finding a violation of Article 6. ${ }^{77}$

Moreover, the Human Rights Committee's reasoning on the merits appears at odds with its own interpretation of Article 6(1) of the ICCPR as reflected in

$70 \quad$ See 'Teitiota v. New Zealand' ( $\mathrm{n}_{3}$ ) para. 9.3.

71 See also Ginevra Le Moli, 'The Human Rights Committee, Environmental Protection and the Right to Life' (2020) 69 International \& Comparative Law Quarterly, 735-52; Katrien Steenmans and Aaron Cooper, 'Ioane Teitiota v New Zealand: A Landmark Ruling for Climate Refugees?' (2020) 25 Coventry Law Journal, 23-32.

72 See 'Teitiota v. New Zealand '(n 3 ) para. 9.7.

73 Ibid, para. 9.8.

74 Simon Behrman and Avidan Kent, 'Prospects for Protection in Light of the Human Rights Committee's Decision in Teitiota v New Zealand' (Forthcoming) Post Migration Review, 7.

75 See 'Teitiota v. New Zealand' (n 3) para. 9.9.

76 See Simon Behrman and Avidan Kent, Prospects for Protection (n 74) 7 .

77 Ibid. 
General Comment No. 36, in which it stated that the right to life is not restricted to mere existence, but encompasses a wider scope, 'to be free from acts and omissions that are intended or may be expected to cause their unnatural or premature death, as well as enjoy a life with dignity.' ${ }^{78}$ Further, the General Comment expressly states that the duty to respect and ensure the right to life requires States parties to refrain from 'deporting, extraditing or otherwise transferring individuals to countries in which there are substantial grounds for believing that a real risk exists that their right to life under article 6 of the Covenant would be violated. ${ }^{79}$ In its decision, the Committee recalled that 'the right to life cannot be properly understood if it is interpreted in a restrictive manner', and stressed that 'the obligation of States parties to respect and ensure the right to life extends to reasonably foreseeable threats and lifethreatening situations that can result in loss of life (...) even if such threats and situations do not result in the loss of life' ${ }^{80}$ This reasoning informed its decision on admissibility, which makes it clear that non-refoulement is applicable in cases where the effects of climate change created a real risk of harm. ${ }^{81}$ However, it does not seem to have been taken into account sufficiently in the decision on the merits, which turns the 'real risk' requirement into a bar to protection so high as to narrow the scope of the right to enjoy a life with dignity. This is made clearer in the two dissenting opinions, discussed below, which both refer to the negative implications of climate change for a life in dignity and emphasise that the standard of proof 'should not be too high and unreasonable. ${ }^{82}$

As mentioned above, on admissibility, the Committee stated that Teitiota's claims relating to the conditions at the time of his removal concern a real predicament or risk caused by lack of potable water and employment possibilities, and a threat of serious violence caused by land disputes. ${ }^{83}$ The admissibility hurdle was satisfied with the Committee essentially recognising the evidence, previously accepted by the New Zealand Tribunal, that the village where Teitiota had resided was overcrowded, has its well impacted by salinization,

78 See General Comment No. 36 (n 18) para. 3. See also Simon Behrman and Avidan Kent, 'The Teitiota Case and the Limitations of the Human Rights Framework' (2020) 75 Questions of International Law, 33.

79 Ibid, para. 3 .

8o See 'Teitiota v. New Zealand' (n 3) para. 9.4.

81 See Simon Behrman and Avidan Kent, The Teitiota Case (n 78 ) 28. See also Ginevra Le Moli (n 71) 747-748.

82 See 'Teitiota v. New Zealand' ( $\mathrm{n}_{3}$ ), dissenting opinion of Duncan Laki Muhumuza, para. 3 .

83 See 'Teitiota v. New Zealand' (n 3) para. 8.5. 
and suffered from regular tidal flooding. ${ }^{84}$ The Committee found that for the purposes of admissibility, it was sufficiently demonstrated by Teitiota that due to the impact of climate change and associated sea level rise on the habitability of Kiribati and on the security situation in the islands, he faced a real risk of impartment to his right to life as a result of New Zealand's decision to remove him to Kiribati.

Particularly striking is that as a matter of fact, the Committee accepted Teitiota's claim that sea level rise is likely to render the Republic of Kiribati uninhabitable within 10 to 15 years. The sheer act of deporting an individual to a country facing such an imminent existential threat without any indication as to how his life in dignity would be safeguarded against this threat seems difficult to reconcile with a State's obligations under Article 6(1) as interpreted in light of General Comment No. 36. In 'Teitiota', the Committee's rationale on this point is based on the consideration that a timeframe of 10 to 15 years 'could allow for intervening acts by the Republic of Kiribati, with the assistance of the international community, to take affirmative measures to protect and, where necessary, relocate its population' ${ }^{85}$ In other words, the Committee seems to suggest that speculative assumptions about 'intervening acts' that could potentially safeguard the right to life are sufficient to meet the requirements of Article 6(1). As McAdam points out, even if it were the case that mitigation and adaptation measures could reduce GHG emissions and enhance resilience to climate change, these measures 'remain uncertain, and they do not detract from the current trajectory of adverse climate change impacts'. ${ }^{86}$ Therefore these measures 'may not be sufficient to reduce an existing real risk (albeit one that will manifest in the distant future)' ${ }^{\prime 8}$ Moreover, the suggestion that the involuntary relocation of the entire population of a State to an as-yetunknown destination is prima facie compatible with the right to life in dignity is highly problematic. ${ }^{88}$

Further questions arise from the mental health impacts related to the deportation to a country affected by climate change. Individuals expecting to be deported home are faced with the prospect of living in a country that will likely become uninhabitable in the near future. During this anticipatory

\footnotetext{
$84 \quad$ Ibid, paras. 2.5, 8.6.

85 Ibid, para. 9.12.

86 See Jane McAdam, Protecting People (n 49) 719, citing Adrienne Anderson et al., 'A Well-Founded Fear of Being Persecuted ... But When?' (2002) 42 Sydney Law Review.

$87 \quad$ Ibid.

88 See e.g. Karen E McNamara and Chris Gibson, "We Do Not Want to Leave Our Land": Pacific Ambassadors at the United Nations Resist the Category of "Climate Refugees" (2009) 40 Geoforum, 475-83.
} 
stage, they may experience feelings of dread, worry and fear, as well as stress and anxiety related to future unpredictability and whether or not survival in their home country will ensue, what future living conditions the change will entail, and more generally, what will become of themselves, their families and people or future generations. ${ }^{89}$ It should also be recalled that the adverse effects impacts of climate change are 'disproportionately felt by [persons] in vulnerable situations, particularly those living in geographically vulnerable developing countries' ${ }^{90}$ Inhabitants of small residents 'experience higher burdens of climate-sensitive health outcomes', ${ }^{91}$ which also includes negative impacts on their mental health. Furthermore, children exposed to climate change hazards and the ensuing displacement are also 'at risk of developing PTSD and other mental health problems like depression, anxiety, phobias and panic, sleep disorders, attachment disorders, and substance abuse. ${ }^{92}$ Finally, once in a location severely affected by climate change, exposure to climate change-related events and impacts can have acute and chronic impacts on an individual's mental health. ${ }^{93}$

It is also worth examining the dissenting opinions issued by two Committee members, referred to above. The first of those, by Vasilka Sancin (Slovenia), disagreed with the Committee's finding of no violation of the right to life, pointing at the failure of the State to present evidence of Teitiota's family's access to safe drinking water in Kiribati. ${ }^{94}$ The second, by Duncan Laki Muhumuza (Uganda), disagreed with the majority in even stronger terms, criticising the majority for placing an unreasonable burden of proof on Teitiota to establish the real risk and danger of arbitrary deprivation of life. More fundamentally, Committee member Laki pointed at the need for the Committee 'to handle critical and significantly irreversible issues of climate change, with the approach

89 Susan Clayton et al., 'Mental Health and Our Changing Climate: Impacts, Implications, and Guidance' (American Psychological Association and ecoAmerica, 2017) <https://www .apa.org/news/press/releases/2017/o3/mental-health-climate.pdf $>27$. See also Christie Manning and Susan Clayton, 'Threats to Mental Health and Wellbeing Associated with Climate Change' in Susan Clayton and Christie Manning (eds), Psychology and Climate Change: Human Perceptions, Impacts, and Responses (Academic Press 2018) 221.

90 See UN Doc A/Hrc/32/23 (n 45) para. 23. See also Betzold Carola, 'Adapting to Climate Change in Small Island Developing States' (2015) 133 Climatic Change Climatic Change, 481-9.

91 WHO, 'Climate Change and Health in Small Island Developing States: A WHO Special Initiative' (2018) <http://www.who.int/iris/handle/10665/279987> 23.

92 Susie E.L. Burke et al., 'The Psychological Effects of Climate Change on Children' (2019) 20 Current Psychiatry Reports, 2.

93 See Susan Clayton et al. (n 89).

94 See 'Teitiota v. New Zealand' (n 3), dissenting opinion of Vasilka Sancin, para. 1. 
that seeks to uphold the sanctity of human life' ${ }^{95}$ After explaining how such an approach is supported by the Committee's own interpretation of Article 6(1) of the ICCPR, he concludes by pointing at the risk of exacerbating what Cape Town Archbishop Emeritus Desmond Tutu has called 'climate apartheid'96 Characterising the measures taken by Kiribati to adapt to climate change as 'laudable', he points out that even if Kiribati does what it can in terms of adaption, for as long as the situation of life remains dire, the standards of dignity required by Article 6(1) will not be met. Accordingly, 'New Zealand's action [of deporting Teitiota to Kiribati] is more like forcing a drowning person back into a sinking vessel, with the "justification" that after all there are other voyagers on board'. ${ }^{97}$ These dissenting opinions underscore the potential of the UN Human Rights Committee, as well as UN treaty bodies more broadly, to contribute significantly to the protection of climate displaced persons.

As a final point, the potential of international human rights mechanisms to contribute to standard-setting on climate displacement depends in significant part on how claims are framed. 'Teitiota', for example, might have delivered better results if the claim would also have addressed the impact of the deportation on Teitiota's right to be free from torture or other cruel, inhuman or degrading treatment as protected under Article 7 of the ICCPR. The question under Article 7 would have been whether the conditions in Kiribati could be said to amount to cruel, inhuman or degrading punishment, so as to trigger non-refoulement obligations. This may have prompted a different analysis than the right to life claim. ${ }^{98}$ The Committee did expressly recognise that 'the effects of climate change in receiving states may expose individuals to a violation of their rights under articles 6 or 7 of the Covenant, thereby triggering the non-refoulement obligations of sending states. ${ }^{99}$ Moreover, a Committee member reportedly suggested that including Teitiota's children as authors of the petition could have influenced the Committee's reasoning favourably.100 The rationale behind this suggestion is that there is an especially strong case for taking a longer-range view of prospective harm in cases involving minor

95 Ibid, dissenting opinion of Duncan Laki Muhumuza, para. 1.

96 United Nations Development Programme, 'Human Development Report 2007/2008: Fighting Climate Change: Human Solidarity in a Divided World' (2007) <http://hdr.undp .org/sites/default/files/reports/268/hdr_20072008_en_complete.pdf>.

97 See 'Teitiota v. New Zealand' (n 3 ), dissenting opinion of Duncan Laki Muhumuza, para. 6.

98 See Jane McAdam, Protecting People (n 49) 716.

99 See 'Teitiota v. New Zealand' (n 3 ) para. 9.11.

100 See Jane McAdam, Protecting People (n 49) 717: This was intimated by one of the Human Rights Committee members at a seminar in February 2020. 
applicants. ${ }^{101}$ By reason of their age, children are inherently more vulnerable to the adverse impacts of natural hazards and climate change. Under Article 3 of the 1989 United Nations Convention on the Rights of the Child, States parties have an obligation to ensure the children such protection and care as is necessary for their well-being. Courts of law are obliged to have regard to the best interests of the child, particularly in allocating the costs and burdens of climate change mitigation and adaption. When assessing the risk of harm with respect to children, a longer time frame therefore would be more appropriate.

All in all, the 'Teitiota' decision provides insight into the potential role of treaty bodies in addressing climate displacement. It has shown, on the one hand, that this potential exists, but on the other hand, it has raised a myriad of new questions about the appropriate legal protection to be given to climatedisplaced peoples.

\subsection{The Standard-Setting Prospects of Pending Climate Cases Billy et al. v. Australia and Sacchi et alv. Argentina et al.}

Two more climate displacement-related cases are currently pending before international human rights mechanisms. If successful, these cases could provide a major step forward in preventing and addressing climate displacement by potentially allowing individuals an opportunity to hold States accountable for the fulfilment of their human rights obligations pertaining to climate change.

In May 2019, a group of indigenous peoples of the Torres Strait Islands lodged a complaint with the UN Human Rights Committee against Australia, alleging violations of their rights in relation to climate-induced rising seas, tidal surges, coastal erosion, and inundation of communities in the Torres Strait Islands in the north of Australia. In this case, known as 'Billy et al. v. Australia', the Islanders seek remedies under the ICCPR for the violations of their rights under Article 27 (right to culture), Article 17 (right to be free from arbitrary interference with privacy, family and home) and Article 6 (right to life) as a result of Australia's inadequate climate mitigation and adaptation. Indigenous peoples are amongst the worst affected by climate change, ${ }^{102}$ and for the Torres Islanders, island culture is evidently impacted by climate change events. ${ }^{103}$

\footnotetext{
101 Adrienne Anderson et al., 'A Well-Founded Fear of Being Persecuted ... But When?' (2002) 42 Sydney Law Review, 174.

102 Margaretha Wewerinke-Singh, State Responsibility, Climate Change and Human Rights under International Law (Hart Publishing 2019) 110.

103 See Owen Cordes-Holland, 'The Sinking of the Strait: The Implications of Climate Change for Torres Strait Islanders' Human Rights Protected by the ICCPR' (2008) 9 Melbourne JIL, 414-17.
} 
The most damaging effect climate change could have on Island culture relates to the displacement of the Islanders from their traditional lands. ${ }^{104}$ Islands are central to Island identity, and Islanders who remain on the islands do not see relocation as an option. Indeed, indigenous peoples often reject migration as a form of adaptation to climate change because they consider their home territory as part of their culture. ${ }^{105}$ As was expressed by the Chairperson of the Torres Strait Regional Authority: 'you cannot move these people because they are connected by blood and bone to their traditional homes.' ${ }^{106}$ These bonds are broken by the loss or uninhabitable character of an indigenous territory.

In their complaint, the Torres Strait Islanders submitted that Australia has a duty to protect their rights by reducing its emissions by at least $65 \%$ below 2005 levels by 2030 and to net zero by 2050, and by phasing out thermal coal, both for domestic electricity generation and export market. ${ }^{107}$ In terms of adaptation, they claimed that the duty to protect these rights involves committing at least $\$ 20$ million for emergency measures such as seawalls, as requested by local authorities - and sustained investment in long-term adaptation measures to ensure the islands can continue to be inhabited. While the communication is still being considered on admissibility (and possibly simultaneously on the merits), the Australian government has already responded to the Islanders' adaptation demands by promising $\$ 25$ million in climate adaptation spending for the Torres Strait. 108

This complaint is the first climate change litigation based on human rights in Australia, and more importantly, it is also the first legal action brought by inhabitants of low-lying islands against a State. The UN Special Rapporteur on Human Rights and the Environment, Professor David Boyd, who along with his predecessor, Professor John Knox, submitted an independent legal brief to the Committee in support of the group's complaint, expressed: 'The effects of the climate crisis are being felt right now by those on the climate frontline, such as residents of smalls islands, but they don't have a seat at the table.109 $\mathrm{A}$

\footnotetext{
104 Ibid., 416.

105 See Margaretha Wewerinke-Singh, State Responsibility (n 102) 111.

106 Ibid.

107 ClientEarth, 'Torres Strait FAQ' (2019) <http://blogs2.law.columbia.edu/climate-change -litigation/wp-content/uploads/sites/16/non-us-case-documents/2019/20190513_Not -Available_press-release.pdf >.

108 ClientEarth, 'Torres Strait Islanders win key ask after climate complaint' (19 February 2020) <https://www.clientearth.org/latest/latest-updates/news/torres-strait-islanders -win-key-ask-after-climate-complaint/>.

109 Darby Ingram, 'Torres Straight eight backed by UN human rights experts' (National Indigenous Times, 18 December 2020) <https://nit.com.au/torres-strait-eight-backed-by -un-human-rights-experts/>.
} 
finding on the merits by the Human Rights Committee in 'Billy et al. v Australia' could help to change this equation for the Torres Strait Islanders by putting pressure on Australia to ensure that some of the Islanders' key demands in connection with climate policy are met. Moreover, it could provide authoritative guidance to all State Parties to the ICCPR on the interpretation of the relevant provisions of the treaty in connection with climate change generally and the prospect of forced internal displacement in particular. As acknowledged by the Committee in General Comment No. 36, the 'implementation of the obligation to respect and ensure the right to life, and in particular life with dignity, depends, inter alia, on measures taken by State parties to preserve the environment and protect it against harm, pollution and climate change.'110 'Billy et al.' provides the Human Rights Committee with an opportunity to clarify what specific measures States must take in this regard, and thus elucidate how State responsibility might arise under international human rights law with respect to climate change and its impacts on island communities and other particularly affected groups. The Committee will also have the opportunity to pronounce on how climate-induced internal displacement can have impacts on the rights to life, culture, and privacy, home and family life of indigenous peoples. It will be particularly interesting to see how the Committee will address the relationship between forced internal displacement in the wider context of the notion of 'culture', which has a prominent place in the case and more broadly in indigenous peoples' human rights claims related to climate change.

A second climate change-related complaint was filed with the UN Committee on the Rights of the Child in September 2019. In 'Sacchi et al v. Argentina et al., sixteen minors filed a petition to the UN Committee on the Rights of the Child against Argentina, Brazil, France, Germany and Turkey, alleging these States make insufficient cuts to greenhouse gases and fail to encourage the world's biggest emitters to curb carbon pollution. As such, those States failed to take the necessary measures to respect, protect, and fulfil the children's rights under Article 6 (right to life), Article 24 (right to health) and Article 30 (right to culture) under the International Convention on the Rights of the Child. The petitioners claim that the Convention on the Rights of the Child must be interpreted in light of the obligations of the respondent under international environmental law. Accordingly, it is asserted that respondents have four related obligations under the Convention: (i) to prevent foreseeable domestic and extraterritorial human rights violations resulting from climate change; (ii) to cooperate internationally in the face of the global climate emergency; (iii) to apply the precautionary principle to prevent deadly consequences even

110 See General Comment No. 36 (n 18) para. 62. 
in the face of uncertainty; and (iv) to ensure intergenerational justice for children and posterity. ${ }^{111}$

Amongst the effects of climate change set out by the petitioners, it was submitted that climate events such as tropical cyclones ${ }^{112}$ and flooding, ${ }^{113}$ have already displaced people, with an estimated 22.5 million people per year on average displaced between 2008 and 2015 as a result of climatic hazards. ${ }^{114}$ The communication stated that events such as floods and tropical cyclones cause long-term displacement, and displaced children specifically will be exposed to multiple risks, such as increasing their vulnerability to child labour and trafficking. More than half a billion children live in extremely high flood occurrence zones, and about 115 million live in areas of high or extremely high risk of tropical cyclones. ${ }^{115}$

The relief requested in the communication is a series of findings by the Committee. The petitioners allege that the respondents are shifting the enormous burden and costs of climate change onto children and future generations, and the primary finding they ask for is a declaration that climate change is a children's rights crisis. The petitioners also ask the Committee, inter alia, to recommend that the respondent nations establish binding and enforceable measures to mitigate the climate crisis, such as reviewing, and where necessary, amending their national and subnational laws and policies to ensure that mitigation and adaptation efforts are being accelerated to the maximum extent of available resources and on the basis of the best available scientific evidence.'116 Another requested recommendation is that each respondent initiate cooperative international action to establish binding and enforceable measures to mitigate the climate crisis, prevent further harm to the petitioners and other children, and secure their inalienable rights.

This petition is historic for attempting to hold multiple States Parties to an international human rights treaty responsible for human rights violations related to climate change, and provides a first opportunity to consider the scope of children's rights in the context of climate displacement. If successful, it could result in a detailed articulation of States' obligations toward children under human rights law and international environmental law. It would, inter alia, clarify the duties and legal obligations that fall on the respondent states to take concrete action to reduce carbon emission and greenhouse gases, and

\footnotetext{
111 See 'Sacchi et al v. Argentina et al'. (n 6).

112 Ibid, para. 83.

113 Ibid, para. 84 .

114 Ibid, para. 86 .

115 Ibid, para. 89.

116 Ibid, para. 328 .
} 
serve to monitor and hold States accountable with respect to the extent to which their climate policies effectively protect human rights, including in connection to climate displacement. First, a decision that climate change is indeed a 'children's rights crisis' would bridge the gap between children's human rights and States' international environmental law obligations. Secondly, a finding that 'each respondent, along with other States has caused and is perpetuating the climate crisis by knowingly acting in disregard of the available scientific evidence regarding the measures needed to prevent and mitigate climate change', could potentially open the door to damages claims against those States by people harmed by climate change. Thirdly, a recommendation that the respondents review or amend their laws to ensure that mitigation and adaptation efforts are accelerated would serve to monitor and hold States accountable with respect to the extent to which their climate policies effectively protect human rights, including in connection with climate displacement. Finally, and of specific relevance to cross-border displacement, a recommendation to initiate and increase cooperative international action would highlight the importance of international cooperation which is essential 'both as a State obligation and as a necessity to address the global challenges created by climate change and related human mobility' ${ }^{\prime 17}$ Such a recommendation would help ensure that the rights of climate displaced people are protected in States of origin, transit or destination, and at any phase of the displacement, and that all policies and actions take into consideration the vulnerability of children.

\section{Potential of Special Procedures of the UN Human Rights Council to Contribute to Standard-Setting on Climate Displacement through Complaint Mechanisms}

Special Procedures of the UN Human Rights Council are independent human rights experts with mandates to report and advise on human rights from a thematic or country-specific perspective. As the first part of this section will demonstrate, existing Special Procedure mandate holders have already played an important role in promoting and protecting human rights through factfinding and clarifying States' obligations in the context of climate change.

Moreover, as the second part of the section sets out, these mechanisms have the potential to contribute to standard-setting concerning the legal protections to be afforded to climate-displaced peoples. Through their complaint mechanisms, which, for the purpose of this article, are most relevant, Special

117 See UN Doc A/Hrc/37/CrP.4. (n 9), para. 10. 
Procedures are in charge of holding inquiries into human rights abuses and to intervene on specific issues or urgent situations following direct individual or group claims. ${ }^{118}$ These complaint mechanisms enable selected mandate holders to receive petitions from the victims of human rights violations (or their representatives) and to communicate with relevant governments to verify the complaint and to press for remedy and redress, thus representing a direct interface between individuals and the UN itself. ${ }^{119}$ As is the case for UN human rights treaty bodies, the use of complaint procedures of Special Procedure mechanisms in the context of climate change also enables mandate holders to deduce and formulate specific standards from generic provisions of international human rights law. Special Procedures are therefore well-situated to clarify the scope of protection for climate displaced peoples available under international human rights law, as well as flag the existence of potential protection gaps. This type of practice can influence State practice as well as decisions of international, regional and domestic courts and quasi-judicial bodies.

\subsection{Special Procedure Mechanisms and Climate Change}

The Special Procedures play an important role in strengthening human rights protections, including in connection with global or transnational human rights issues such as climate displacement. They include Special Rapporteurs, Independent Experts and Working Groups. ${ }^{120}$ As of September 2020, the UN human rights system boasts forty-four thematic mandates and eleven country mandates. ${ }^{121}$ Special Procedures undertake country visits; act on individual cases and concerns of a broader, structural nature by sending communications to States and other actors bringing alleged violations or abuses to their attention; conduct thematic studies and convene expert consultations; contribute to the development of international human rights standards; engage in advocacy; raise public awareness; and provide advice for technical cooperation. ${ }^{122}$ Special Procedures contribute to the elaboration, interpretation, and

118 Marc Limon and Ted Piccone, 'Policy Report: Human Rights Special Procedures: Determinants of Influence' (Universal Rights Group, 2014) <https://www.universal-rights.org/ wp-content/uploads/2015/o2/URG_Human_rights_special_procedures_pge_by_pge_hd .pdf $>, 27-28$.

119 Ibid.

120 UN онснR, 'Special Procedures of the Human Rights Council <www.ohchr.org/EN/HR Bodies/SP/Pages/Welcomepage.aspx $>$.

121 Ibid.

122 HR Council, 'Special Procedures' <https://www.ohchr.org/EN/HRBodies/HRC/Pages/ SpecialProcedures.aspx\#: :text=Special\%2oprocedures\%2oundertake\%2ocountry\%2O visits,contribute\%2oto\%2othe\%2odevelopment\%2oof $>$. See also Marc Limon and Ted Piccone (n 118) 23. 
acceptance of human rights norms through their regular reports to the Human Rights Council and (in some cases) to the General Assembly, the contents of which may then be reflected in Council and/or General Assembly resolutions. ${ }^{123}$ This contribution is also made through the elaboration of soft law instruments such as UN guidelines. ${ }^{24}$ Special Procedures have also advanced the development of international standards and other soft law instruments to help promote the implementation of those norms, with one example being the UN Guiding Principles on internal displacement. ${ }^{125}$ As Limon and Piccone observe, their effectiveness is the product of six main structural determinants of influence: independence and accountability; expertise and standing; flexibility, reach and accessibility; cooperation; implementation and follow-up; and the availability of resources and support. ${ }^{126}$

In the climate change context, the Special Procedure mechanisms have been actively involved in addressing the human rights impacts of climate change under their respective mandates through reports, country visits, statements and press releases and contributions to Human Rights Council debates, seminars and panel discussions. ${ }^{127}$ In 2015, for instance, a number of UN human rights mandate holders published a report chronicling the range of adverse effects that climate change can have on human rights, including in the context of climate displacement. ${ }^{128}$ Different holders of the mandate of Special Rapporteur (and previously Special Representative of the UN Secretary General) on the Human Rights of Internally Displaced Persons, ${ }^{129}$ and of the Special Rapporteur on the Human Rights of Migrants have also dedicated specific attention to climate displacement. ${ }^{130}$

The mandate of the UN Special Rapporteur on the Human Rights of Internally Displaced Persons, for instance, was created to address the problem of internal displacement, work towards strengthening the international

123 Surya Subedi, “The UN Human Rights Special Rapporteurs and the Impact of their Work: Some Reflections of the UN Special Rapporteur for Cambodia' (2015) 6 Asian Journal of International Law, 3 .

124 See Marc Limon and Ted Piccone (n 118) 26.

125 Ibid.

126 Ibid., 12.

127 See UN OHCHR, Human rights mechanisms addressing climate change (n 17).

128 Special Procedures of the United Nations Human Rights Council, 'The Effects of Climate Change on the Full Enjoyment of Human Rights' (30 April 2015) <https://unfccc.int/files/ science/workstreams/the_2013-2015_review/application/pdf/cvf_submission_annex_1 _humanrights.pdf $>$.

129 See, for instance, UNGA, 'Protection of and assistance to internally displaced persons' (9 August 2011) UN Doc A/66/285.

130 See, for instance, UNGA, 'Human rights of migrants' (13 August 2012) UN Doc A/67/299. 
response to internal displacement, and engage in action and dialogue with relevant actors to improve the protection and respect of the human rights of internally displaced persons. ${ }^{131}$ The Special Rapporteur has published extensively on the relationship of climate change on internal displacement. For instance, in the July 2020 report on internal displacement in the context of slow-onset adverse effects of climate change, the Special Rapporteur analyses the impacts of this type of displacement on the enjoyment of human rights by internally displaced persons, including specific groups, examines the human rights obligations, responsibilities and roles of States, the international community, businesses and national human rights institutions in addressing internal displacement in the context of the slow-onset adverse effects of climate change, and makes recommendations to these actors. ${ }^{132}$

Similarly, the mandate of the UN Special Rapporteur on the Human Rights of Migrants was created to examine the ways and means to overcome the obstacles existing to the full and effective protection of the human rights of all migrants at all stages of migration, and to elaborate recommendations on strengthening the promotion, protection and implementation of the human rights of all migrants. ${ }^{133}$ With respect to climate change, the Special Rapporteur examined the impacts of climate change and some of its consequences for migration, whilst providing recommendations to help guide states in developing appropriate responses to the issue. ${ }^{134}$ For example, some proposed measures include conducting risk assessments, providing public participation risk assessments, providing public participation opportunities, and ensuring

\footnotetext{
131 UN онснв, 'Special Rapporteur on the Human Rights of Internally Displaced Persons' <https://www.ohchr.org/EN/Issues/IDPersons/Pages/IDPersonsIndex.aspx >.

132 UNGA, 'Human rights of internally displaced persons' (21 July 2020) UN Doc A/75/207. See also: UNGA, 'Rights of internally displaced persons' (3 August 2016) UN Doc A/71/279; HR Council, 'Report of the Special Rapporteur on the human rights of internally displaced persons, Chaloka Beyani' (1 April 2015) UN Doc A/H RC/29/34; HR Council, 'Report of the Special Rapporteur on the human rights of internally displaced persons, Chaloka Beyani' (26 December 2011) UN Doc A/HRC/19/54; HR Council, 'Report of the Special Rapporteur on the human rights of internally displaced persons, Chaloka Beyani - Addendum Mission to Maldives' (30 January 2012), UN Doc A/HRC/19/54/Add.1; HR Council 'Report of the Special Rapporteur on the human rights of internally displaced persons, Chaloka Beyani' (9 August 2011) UN Doc A/66/285.

133 UN оHCHR, 'Special Rapporteur on the human rights of migrants $<$ https://www.ohchr .org/EN/Issues/Migration/SRMigrants/Pages/SRMigrantsIndex.aspx >.

134 See UN Doc A/67/299 (n 130). See also UNGA, 'Human rights of migrants' (4 August 2016) UN Doc A/71/285.
} 
that there are human rights safeguards for all programs to manage migration and displacement. 135

Other Special Procedures have also made statements related to displacement in the context of climate change. In a mapping report to the Human Rights Council, the Independent Expert on human rights and the environment discussed the duty to provide access to legal remedies and referred to a statement by the Committee on Economic, Social and Cultural Rights urging States to provide for just compensation to and resettlement of indigenous peoples displaced by deforestation. ${ }^{136}$ The Special Rapporteur on Human Rights and the Environment also recognised in a report that climate change is an increasingly important contributor to displacement and migration, both within nations and across international borders. ${ }^{137}$ The report specified that natural hazards and environmental harm often cause internal displacement and transboundary migration, ${ }^{138}$ which have adverse impacts on health, ${ }^{139}$ and more generally, can exacerbate vulnerabilities and lead to additional human rights violations and abuses. ${ }^{140}$

Though the powers of Special Procedure mandate holders are discretionary and do not go beyond diplomacy, Special Procedures could generate political pressure which, combined with legal action before a domestic court, could result in tangible redress for human rights implications of climate change. ${ }^{141}$ Even more so, Special Procedures could provide targeted support in litigation, including as a type of third-party intervention at the mandate holder's initiative. This was demonstrated by the Special Rapporteur on Human Rights and the Environment, David Boyd, who submitted an expert statement in relation to the case 'Friends of the Irish Environment CLG v. The Government of

135 See UN Doc A/67/299 (n 130) paras. 39, 73-76, 93. See also UNEP and Colombia Law School, 'Climate Change and Human Rights' (2015) < https://web.law.columbia.edu/sites/ default/files/microsites/climate-change/climate_change_and_human_rights.pdf>.

${ }_{13} 6$ HR Council, 'Report of the Independent Expert on the issue of human rights obligations relating to the enjoyment of a safe, clean, healthy and sustainable environment, John H. Knox' (3o December 2013) UN Doc A/HRC/25/53, para. 41.

137 UNGA, 'Human rights obligations relating to the enjoyment of a safe, clean, healthy and sustainable environment' (15 July 2019) UN Doc A/74/161, para. 7 .

138 UNGA, 'Human rights obligations relating to the enjoyment of a safe, clean, healthy and sustainable environment' (19 July 2018) UN Doc A/73/188, para. 24 .

139 UNGA, 'Human rights obligations relating to the enjoyment of a safe, clean, healthy and sustainable environment' (15 July 2019) UN Doc A/74/161, paras. 7, 31.

140 See UN Doc A/73/188 (n 138), para. 24.

141 See Margaretha Wewerinke-Singh, Litigating Human Rights Violations (n 47) 110-11. 
Ireland, Ireland and the Attorney General', a rights-based climate case brought before the High Court of Ireland. ${ }^{142}$

In passing, it is worth noting that some States and numerous civil society organisations have called for the establishment of a UN Special Rapporteur on Human Rights and Climate Change. In light of the need for a stronger human rights-based approach to climate change, such a position would ensure greater consistency in the way the Human Rights Council and other human rights institutions address human rights and climate change. ${ }^{143}$ Complaints submitted to such a Rapporteur would help further clarify States' obligations and responsibilities in terms of climate change and human rights by focusing specifically on and holistically addressing climate change. As has been argued in the context of natural hazards, such a mandate would provide a 'central focal point within the UN human rights monitoring system to ensure the consistent application and awareness of the human rights implications of climate displacement.'. ${ }^{44}$

\subsection{Potential of Special Procedure Mechanisms to Contribute to Standard-Setting on Climate Displacement}

Like UN treaty bodies, Special Procedures mechanisms are in a unique position to consider individual complaints regarding climate displacement. The prime basis for Special Procedures' mandates is to be found in international law, and in particular, in the Charter of the United Nations and the Universal Declaration of Human Rights. ${ }^{145}$ The main reference points of these mechanisms range from the general provisions of the UDHR and other internationally recognised human rights standards to the specific terms of their mandates from the Human Rights Council. As noted above, they may rely on particular instruments of 'hard' treaty law as well as 'soft' law of declarations, resolutions

142 David R. Boyd, 'Statement on the human rights obligations related to climate change, with a particular focus on the right to life' $(25$ October 2018) <https://www.ohchr.org/ Documents/Issues/Environment/FriendsIrishEnvironment25Oct2018.pdf>.

143 See discussion in Clémence Billard, Schachter and Francesca Mingrone, 'A UN Special Rapporteur on Human Rights \& Climate Change?' (CIEL and Franciscans International, January 2021) <https://www.ciel.org/wp-content/uploads/2021/o2/UNSR-Report_English $-2-5 . p d f>$.

144 Dug Cubie and Marlies Hesselman 'Accountability for the Human Rights Implications of Natural Disasters: A Proposal for Systemic International Oversight' (2017) 33 Netherlands Quarterly of Human Rights, 36 .

145 HR Council, 'Implementation of General Assembly Resolution 6o/251 of 15 March 2006 Entitled "Human Rights Council"' (18 June 2007) UN Doc A/H RC/5/L.3/Rev.1, preambular para. 1. See also Oliver Hoehne, 'Assessing Special Procedures and the New Human Rights Council - A Need for Strategic Positioning' (2007) 4 Essex Human Rights Review, 54. 
and guiding principles. ${ }^{146}$ In this regard, when assessing claims related to climate displacement, these mechanisms are equally informed by international human rights norms reflected in these sources which embody globally shared values.

Secondly, Special Procedures derive their mandates from the Human Rights Council which, due to its subsidiary status, has important institutional links with its parent body, the UN General Assembly. ${ }^{147}$ Special Procedures report to the Human Rights Council and serve as its "eyes and ears". 148 These mechanisms are able to engage with member States through communications in order to help further their human rights compliance as well as respond to human rights concerns. This engagement means that the communications and recommendations issued by the Special Procedures on individual complaints are authoritative, and has resulted in human rights standard-setting on the subject matter concerned, whether through the adoption of a resolution, a declaration by the UNGA, or even the conclusion of a new treaty. ${ }^{149}$ Factual examinations of human rights violations, conducted by these Special Procedures following individual or group complaints, would help clarify existing legal obligations and provide guidance for States on their human rights obligations with respect to climate displacement, in addition to potentially being useful in assisting human rights treaty bodies when rendering their conclusions in climate-related cases. The findings of these mechanisms on these complaints are legally significant as a result of the Special Procedures' mandate and their independence, especially where they pronounce on the existence of violations of human rights or make recommendations for adherence to human rights standards. Moreover, as Subedi points out, when the recommendations made by Special Rapporteurs are implemented by States, this can serve as evidence of opinio juris and give rise to the crystallisation of the norms recommended into rules of customary international law. ${ }^{150}$ As such, the work of Special Rapporteurs could contribute to standard-setting in international law on climate displacement through the elaboration of their recommendations,

146 Ted Piccone, Catalysts for Change: How the UN's Independent Experts Promote Human Rights (Brookings Institution Press 2012) 8.

147 Emmanuel Bichet and Stephanie Rutz, 'Policy Paper: The Human Rights Council as a Subsidiary Organ' (Universal Rights Group, 2016) <https://www.universal-rights.org/wp -content/uploads/2016/11/Policy-Paper-HRC-as-a-subsidiary-organ.pdf>, 4.

148 Surya Subedi, 'Protection of Human Rights through the Mechanism of UN Special Rapporteurs' (2011) 33 Human Rights Quarterly 201, 204.

149 See Surya Subedi, The UN Human Rights (n 123) 3.

150 Ibid. 
through an international instrument, or through their development of customary international law. ${ }^{151}$

Third, as is the case with UN treaty bodies, the pool of Special Procedure mandate holders is more geographically diverse than that of most other judicial or quasi-judicial bodies confronted with climate change cases. In 2014, for instance, the distribution of Special Procedures mandate holders amongst regional groups was at follows: $27 \%$ African, $21 \%$ Asia-Pacific, $12 \%$ Eastern European, $17 \%$ Latin American and Caribbean, and 23\% Western European and Others. ${ }^{152}$ Notably, several Special Procedure mandate holders are nationals of climate vulnerable States. For example, the current Special Rapporteur on the human rights of internally displaced persons is from the Philippines, ${ }^{153}$ and a former mandate holder was from Sudan; ${ }^{154}$ the current Special Rapporteur on the rights of indigenous people is from Guatemala, ${ }^{155}$ and the previous mandate-holder was from the Philippines; ${ }^{156}$ a former Special Rapporteur on the human rights of migrants was from Costa Rica. ${ }^{157}$ Again, mandate holders as nationals from different States are in a better position to understand the needs of diverse individual or groups of individuals when assessing cases of climate change-related displacement and the relevant legal obligations. They are also likely to be sensitive to local contexts, and able to identify opportunities for regional and international cooperation to prevent and redress such violations.

Fourthly, their inherent flexibility as well as the range of human rights issues it is able to address make Special Procedures particularly suitable for filing innovative human rights complaints relating to climate change-related displacement. On the one hand, in the context of assessments under the Special

\footnotetext{
$15^{1}$ Ibid.

$15^{2}$ See Marc Limon and Ted Piccone, Policy Report (n 118) 14.

153 Ms. Cecilia Jimenez-Damary: UN онснг 'Ms. Cecilia Jimenez-Damary, Special Rapporteur on the human rights of internally displaced persons' <https://www.ohchr.org/EN/ Issues/IDPersons/Pages/CeciliajimenezDamary.aspx>.

154 Mr. Francis Deng: UN онснR, 'Special Rapporteur on the Human Rights of Internally Displaced Persons' <https://www.ohchr.org/en/issues/idpersons/pages/idpersonsindex .aspx $>$.

155 Mr. José Francisco Calí Tzay: UN онснг, Francisco Calí Tzay, Special Rapporteur on the rights of indigenous peoples' <https://www.ohchr.org/EN/Issues/IPeoples/SRIndigenous Peoples/Pages/FranciscoCali.aspx>.

156 Ms. Victoria Tauli-Corpuz: UN онCHR, 'Victoria Tauli-Corpuz' <https://www.ohchr.org/ en/issues/ipeoples/srindigenouspeoples/pages/victoriataulicorpuz.aspx $>$.

157 Ms. Gabriela Rodríguez Pizarro: UN онснR, 'Special Rapporteur on the human rights of migrants' <https://www.ohchr.org/en/issues/migration/srmigrants/pages/srmigrants index.aspx $>$.
} 
Procedure mechanisms, victims' abilities to complain do not depend on the ratification of human rights treaties by their own State; there are usually no jurisdictional restrictions on the scope of complaints; domestic remedies do not need to be exhausted; complaints could refer to the past, ongoing, as well as potential future violations; and victims may identify any State or non-State actor as the alleged perpetrators of the violation. On the other hand, because they are not limited to any particular treaty, nor human right, ${ }^{158}$ Special Procedures can consequently address different instruments and rights at once. ${ }^{159}$ This makes their findings more holistic in nature, which is particularly useful in new, innovative human rights claims. With just one climate-related complaint filed under the Special Procedures' complaint procedures to date, the potential of these mechanisms to contribute to standard-setting on climate displacement seems to be under-utilised. At the same time, as the remaining part of this section demonstrates, this first complaint is particularly promising in terms of its standard-setting potential as it addresses climate displacement head-on and asks for a range of innovate remedies.

\subsection{The Standard-Setting Prospects of the Pending Climate Case Filed by the Alaska Institute for Justice on Behalf of the Five U.S. Indian Tribes to the UN Special Rapporteurs}

In January 2020, the Alaska Institute for Justice filed a complaint on behalf of five U.S. Indian tribes in Alaska and Louisiana addressed to several UN Special Rapporteurs. In their complaint titled 'Rights of Indigenous People in Addressing Climate-Forced Displacement', the tribes invoked, inter alia, the right to self-determination and culture under the Declaration on the Rights of Indigenous People, the right to life under Article 6 of the ICCPR, and the right to food under the ICESCR. Specifically, the tribes call on the Special Rapporteurs to recommend that the United States government recognise climate displacement as a human rights issue and take steps to address this type of displacement, including by recognising the self-determination and inherent sovereignty of all the tribes, funding the tribal-led relocation processes for the native village of Kivalina and Isle de Jean Charles, and granting federal recognition to the tribal nations in Louisiana for them to be able to access federal resources for adaptation and disaster response. ${ }^{160}$

What is particularly interesting about this complaint is that in addition to calling attention to the human rights impacts of climate displacement, it

158 See Marc Limon and Ted Piccone, Policy Report (n 118) 15.

159 See Ted Piccone (n 146) 8.

16o See Complaint (n 7) 10, 11. 
expressly uses the term 'displacement'. It has been argued that 'recent international processes have skirted around the issue of whether people who leave home because of climate-related disasters are forced to do so, or do so by choice', ${ }^{161}$ and as an example, the Global Compact on Safe, Orderly, and Regular Migration refers to migrants 'compelled to leave their countries of origin' as a result of a natural hazard, but never uses the term 'displacement'. ${ }^{162}$ Framing the issue as one of forced displacement may therefore encourage the development of more robust international legal obligations, similar to the ones owed to refugees. ${ }^{163}$ Seeing as international law recognises certain classes of forced migrants as people whom other countries have an obligation to protect namely, internally displaced persons (IDPS), refugees, stateless persons and those eligible for complementary protection in light of non-refoulement obligations, ${ }^{164}$ defining the concept of climate change migration as inherently a form of forced displacement can serve to build a new legal framework to address forced climate displacement, in which there is recognition of a new category of people worthy of international protection. In this regard, these Special Rapporteurs, who each have a different mandate, can recommend establishing alternative forms of protection for those persons who, albeit not qualifying as refugees, are equally forcibly displaced, and whose return is not feasible or not reasonable due to circumstances in the place of origin and/or personal conditions, including particular vulnerabilities. These recommendations would help define this category of forcibly displaced persons, as well as provide more clarity as to the scope of their protection.

Further, this complaint is the first to specifically address internal displacement as a result of climate-related impacts. A report from the view of not one, but ten Special Rapporteurs whose mandates all concern human rights which, in one way or another, are impacted by climate change would help clarify the scope of protection of internally climate displaced people available under

161 Ama Francis, 'U.S. Tribes Claim U.S. Government Violates Human Rights Obligations by Failing to Address Climate-Forced Displacement' (Sabin Center for Climate Change Law at Columbia University, 28 February 2020) <http://blogs.law.columbia.edu/climate change/2020/02/28/us-tribes-claim-u-s-government-violates-human-rights-obligations -by-failing-to-address-climate-forced-displacement/>.

162 Ibid.

163 Ibid.

164 Jane McAdam, 'Climate Change Displacement and International Law: Complementary Protection Standards' (UNHCR - Legal and Protection Policy Research Series, May 2011) <https://www.unhcr.org/protection/globalconsult/4dffi6e99/19-climate-change-dis placement-international-law-complementary-protection.html>. See also Walter Kälin, 'Conceptualising Climate-Induced Displacement' in Jane McAdam (ed), Climate Change and Displacement - Multidisciplinary Perspectives' (Hart Publishing 2010). 
international human rights law - including from the perspective of indigenous peoples - and identify the existence of protection gaps, including in connection with international cooperation and assistance for climate vulnerable States. This kind of report could influence State practice as well as decisions of international, regional and domestic courts and quasi-judicial bodies with respect to climate displacement, and could also provide targeted support in litigation, as a type of third-party intervention for instance, should the U.S. tribes decide to pursue domestic action.

On 15 September 2020, the UN Special Rapporteurs sent a communication to the U.S. requesting additional information on the allegations made in the complaint. ${ }^{165}$ The Special Rapporteurs express their concerns about, inter alia, the displacement of indigenous peoples from their ancestral lands triggered by the loss of land, ecosystems and biodiversity resulting from the climate events including the environmental impacts of the oil and gas exploration in the Louisiana coast and of the Mississippi River levee system and recurrent disasters.

In the Annex, the Special Rapporteurs refer the U.S. to the applicable international human rights instruments and standards in connection with the complaint, including on the subject of displacement. The Special Rapporteurs first draw the U.S.' attention to the 1998 Guiding Principles on Internal Displacement, stressing in particular that under Principle 6 people have a right to be protected against being arbitrarily displaced, and under Principle 9 States are obliged to protect against the displacement of indigenous peoples and other groups with a special dependency on and attachment to their lands. ${ }^{166}$ Interestingly, the Special Rapporteurs also point out that the right to housing as protected under Article 11(1) of the ICESCR includes legal protection against 'forced evictions', a term which was not mentioned in the complaint. This point is elaborated in four paragraphs, drawing on the practice of the Committee on Economic, Social and Cultural Rights, the Special Rapporteur on the right to housing, and a range of international 'soft law' instruments on forced evictions. The Special Rapporteurs do not elaborate on the specific ways in which these standards apply to situations of climate displacement or the threat thereof; a question that has received some attention in legal scholarship, ${ }^{167}$ and that would merit further attention in the evolving practice on climate litigation.

165 UN онснR, Communication to the United States of America (15 September 2021), USA $16 / 2020$.

166 Ibid., 10.

167 See e.g. Sébastien Jodoin, Kathryn Hansen and Caylee Hong, 'Displacement Due to Responses to Climate Change: the Role of a Rights-Based Approach' in Benoit Mayer and François Crépeau (eds), Research Handbook on Climate Change, Migration and 
In a time where islands are being submerged by rising sea levels, countries are battered by tropical storms, and people are swimming across borders to reach safe haven, international human rights mechanisms can serve as a vessel of protection. UN human rights treaty bodies and Special Procedures have significant potential to contribute to standard-setting on climate displacement. This potential is readily apparent from the Human Rights Committee's views on 'Teitiota', which unambiguously confirms the applicability of international human rights law to situations of climate displacement, notably including cross-border displacement. The Committee's recognition of this connection underscores that States' discretion to deny protection to climate displaced persons is limited by their respective obligations under international human rights law. At the same time, however, the Committee's views raise new questions about the scope and nature of these obligations, and may even be interpreted as indicating that protection is to be provided only in the most dire of crossborder displacement situations. This underwhelming outcome may be due to shortcomings in the initial claim, such as the fact that the author's children were not included as authors of the communication and thus potential violations of their Covenant rights resulting from the family's deportation were not considered. Other factors that may have prevented the Committee from pronouncing more progressively on the issue include potential reluctance to open the so-called floodgates to similar claims on behalf of climate displaced persons, or a lack of familiarity with the scientific and legal intricacies of climate displacement.

Against this backdrop, the three other climate-related claims that are pending before international human rights mechanisms provide new opportunities for these mechanisms to contribute to standard-setting in relation to climate displacement. Of particular importance are the potential of 'Billy et al.' to clarify the scope and content of States' obligations to respect the right to culture in connection with forced displacement of indigenous communities;

the Law (Edward Elgar 2017); Idowu Ajibade and Damilola S. Olawuyi, 'Climate Change Impacts on Housing and Property Rights in Nigeria and Panama: Towards a Rights-Based Approach to Adaptation and Mitigation' in Dominic Stucker and Elena Lopez-Gunn (eds), Adaptation to Climate Change through Water Resources Management (Routledge 2014); Bruce Burson et al, 'The Duty to Move People Out of Harm's Way in the Context of Climate Change and Disasters' (2018) Refugee Survey Quarterly, 379-407; Margaretha Wewerinke-Singh and Tess Van Geelen, 'Protection of Climate Displaced Persons under International Law: A Case Study from Mataso Island, Vanuatu' (2018) 19 Melbourne Journal of International Law, 666-702. 
the potential of 'Sacchi et al.' to provide greater clarity on States' obligations to ensure that their domestic climate policies do not result in infringements of human rights outside their own territories; and the potential of 'Rights of Indigenous People in Addressing Climate-Forced Displacement' to shed light on States' obligations to provide financial and other forms of assistance for community-led relocation processes.

In sum, the cases discussed in this article illustrate the potential of international human rights mechanisms' complaint procedures to address a range of issues that have proven difficult or impossible to resolve through policymaking or negotiations. Future strategic litigation in this area could add to this potential by focusing on obligations of international cooperation and assistance to prevent and address cross-border climate displacement, including the extent to which States that have made the greatest historical contributions to climate change have special obligations in this regard based on the principle of common but differentiated responsibilities and respective capabilities. ${ }^{168}$ Even if unsuccessful, new and pending cases could contribute to articulating both cross-border and internal climate displacement as a human rights issue, which in turn could inspire new laws, policies or indeed adjudication to enhance protection of climate displaced persons.

168 See Joanna Setzer and Rebecca Byrnes, 'Global Trends in Climate Change Litigation: 2019 Snapshot' (Grantham Research Institute on Climate Change and the Environment, 4July 2019) <https://www.lse.ac.uk/granthaminstitute/wp-content/uploads/2019/o7/GRI _Global-trends-in-climate-change-litigation-2019-snapshot-2.pdf>, and also Jacqueline Peel and Hari Osofsky, 'Climate Change Litigation' (2020) 16 Annual Review of Law and Social Sciences, 21-38. 